\title{
Post-supplementation nutrient profiles of proteins, amino acids and DNA in Macrobrachium rosenbergii PL-15
}

\author{
Anne Rebecca A. ${ }^{*}$ (D) and Saravana Bhavan P. ${ }^{2}$
}

\begin{abstract}
Background: The study was indented to obtain a protein profile pattern using SDS-PAGE, an amino acid profile pattern using high-performance thin-layer chromatography, and a DNA profile pattern using agarose gel electrophoresis in Macrobrachium rosenbergii (post larva (PL)-15) after oral supplementation with three herbs, namely, Allium sativum, Curcuma longa, and Zingiber officinale. Each herb was individually supplemented along with a basal feed mix at 1\%,3\%, and 5\% for 90 days to the corresponding experimental groups. Control groups were offered only the basal feed mix (0\% supplementation). Proteins were extracted and electrophoresed. Amino acids were extracted and chromatographed. DNA was isolated and electrophoresed.

Results: The study revealed the superlative performance of $Z$. officinale, which when supplemented at the $5 \%$ level, promoted synthesis of $66-\mathrm{kDa}, 41-\mathrm{kDa}, 15-\mathrm{kDa}$, and $13-\mathrm{kDa}$ proteins; synthesis of certain essential amino acids including lysine and methionine; stabilized the integrity of DNA.

Conclusion: The presence of nutraceuticals such as alkaloids, flavonoids, pigments, phenolics, terpenoids, steroids, and essential oils in the supplemented herbs is the causative factor for increased nutritional quality through higher rates of transcription and antioxidation, in addition to the bioenhancer effect, which promoted protein intake.
\end{abstract}

Keywords: Aquaculture, Aqua feed, Sustainable aquaculture, Macrobrachium rosenbergii, Prebiotics, Nutraceuticals, Bioenhancers, Allium sativum, Curcuma longa, Zingiber officinale

\section{Background}

"Prebiotics" are defined as substances that induce the growth or activity of microorganisms that contribute to the well-being of their host (Hutkins et al., 2016). Allium sativum, Curcuma longa, and Zingiber officinale are among the well-documented prebiotics (Kurhekar, 2013; Lu et al., 2017; Mona, Rizk, Salama, \& Younis, 2015). These herbs also act as" nutraceuticals" and "bioavailability enhancers/absorption enhancers" (Kesarwani \& Gupta, 2013; Shylaja \& Peter, 2007; Tatiraju, Bagade, Karambelkar, Jadhav, \& Kadam, 2013). Z. officinale has a powerful effect on the gastrointestinal tract mucous membrane. It regulates the intestinal function to facilitate absorption. Allicin, the active bioenhancer phytomolecule in A. sativum, and Curcumin in C. longa is

\footnotetext{
* Correspondence: annerebecca.rebecca@gmail.com

'Department of Zoology, PSG College of Arts and Science, Coimbatore,

Tamilnadu 641014, India

Full list of author information is available at the end of the article
}

reported to have a bioenhancer effect Therefore, these functional compounds are assumed to behave as epigenetic factors.

Inclusion of A. sativum, C. longa, and Z. officinale is also sustainable. Herb-based aqua-feed formulations are better replacements for antibiotics. Feed costs represent around $80 \%$ of the total operating costs (El-Sayed, 1999). Herb-based aqua-feed formulation is low cost, sustainable, and environmental and consumer safe which positively influence growth rates. Improvement in growth rates on the other hand reduces the culture period, which is profitable in the agriculture sector (Keshavanath, Gangadhara, \& Khadri, 2003). Supplementing medicinal plants is reported to improve meat quality and reduce market price (Bhavan et al., 2010). Imparting nutraceuticals and bioenhancers is suitable for commercially farmed aquatics species like $M$. rosenbergii as compared to marine species. $M$. rosenbergii is the largest natantian (swimming) prawn in the world (Nandlal \& Pickering, 2005) and is reported to have rich 
nutrition with unique delicacy (Bhavan et al., 2010). Therefore, it is favored among children and a substitute for malnutrition (Devi, Hareesh, \& Reddy, 2015). Its farming also provides employment opportunity (Rebecca \& Bhavan, 2011).

Studies on morphometric and nutritional indices in $M$. rosenbergii PL fed with $A$. sativum, C. longa, and Z. officinale have already been reported by Rebecca and Bhavan (2014). The present study focuses on nutritional profile patterns obtained through electrophoretic and chromatographic techniques.

\section{Materials and method Feed preparation}

Feed formulation was done using the Pearson square method, and the protein content in the feed was equated to $40 \%$ (Wagner \& Stanton, 2012). Thirty-eight percent fish meal, $40 \%$ groundnut oilcake, $3 \%$ coconut oilcake, $3 \%$ wheat bran, $3 \%$ rice bran, $3 \%$ maize bran, and $2 \%$ tapioca flour were taken as the basal feed mix. These were steam cooked at $95{ }^{\circ} \mathrm{C} / 5 \mathrm{~min}$ and then cooled to room temperature. Herbal powders as supplement, egg albumin as binder, vitamins, and cod liver oil an essential fatty acid source were added to the mix. The mix was made to thick dough with water. Fine feed pellets were obtained by squeezing the fresh dough through a hand-made feed pelletizer (pore diameter $3 \mathrm{~mm}$ ). The pellets were fan dried and stored at room temperature. For preparation of herbal supplements, bulbs of $A$. sativum, rhizomes of $C$. longa, and rhizomes of $Z$. officinale were de-skinned, dried, and powdered and are taken separately. These were added individually at $1 \%, 3 \%$, and $5 \%$ levels to the basal feed mix. The feed with 100\% basal ingredients, exclusion of the herbal supplementation, served as a control diet.

\section{Experimental setup}

A 90-day experiment was carried out. $M$. rosenbergii post larva-15 (average weight, $0.1 \mathrm{~g}$ ) were purchased from Kerala district of India, allowed to acclimatize for a week, and maintained at laboratory conditions. The animals were divided into ten groups and fed with their respective feed. The feed was offered as $10 \%$ of body weight.

Molecular weight markers were obtained from Medox-Bio Chemicals, Pvt. Ltd., India. All other reagents were of analytical grade and purchased from Himedia Chemicals Pvt. Ltd., India.

\section{Protein analysis}

The preparation and analysis of proteins by SDS-PAGE was done following the method of Laemmli (1970).

\section{Extraction}

From each group, $1 \mathrm{~g}$ of muscle tissue was homogenized in phosphate buffer, $\mathrm{pH}-7.4$, at $4{ }^{\circ} \mathrm{C}$ and then centrifuged at $1500 \mathrm{rpm}$ for $5 \mathrm{~min}$. Supernatant is separated and used further. Supernatant protein content is determined by Lowry et al. (1951). Fifty micrograms protein/load was taken with sample loading buffer. Fifty microliters of the total volume mixture/lane was taken, heated sufficiently for 2 min to ensure complete interaction between protein and SDS, cooled thoroughly, and then used for electrophoresis.

\section{Preparation}

The $4 \%$ stacking gel, $10 \%$ separating gel, $0.1 \%$ Coomassie brilliant blue R-250 in gel stain, and 0.01\% Bromophenol blue as a tracking dye in sample buffer were used. Marker proteins include $\beta$-galactosidase $(116 \mathrm{kDa})$, bovine serum albumin $(66 \mathrm{kDa})$, ovalbumin $(45 \mathrm{kDa})$, carbonic anhydrase $(29 \mathrm{kDa})$, soybean trypsin inhibitor $(20$ $\mathrm{kDa})$, and lysozyme $(14 \mathrm{kDa})$.

\section{Analysis}

The samples were allowed to run on vertical slab gel. The gel, after subjecting to staining with Coomassie brilliant blue R-250 and de-staining process with acetic acid, was then subjected to alcohol wash to fix the gel for limiting diffusion of protein bands from the matrix. Movement distance of the protein was observed as a clear line for each sample and compared with a protein marker. $R$ value for each band was calculated by

\section{$\mathrm{Rf}=$ band distance from first distance band of first distant to reference point}

A graph of the Rf value of standard protein with log molecular weight for each protein was formed. Molecular weight of each sample of protein can be defined by a calibration curve based on the $\mathrm{Rf}$ value of a sample (Hoffman, 1977).

\section{Analysis of amino acids}

The preparation and analysis of proteins by high-performance thin-layer chromatography (HPTLC) was done following the method of Hess and Sherma (2004).

\section{Extraction}

One gram of muscle tissue from each group was dried $\left(80^{\circ} \mathrm{C}\right.$ for $\left.3 \mathrm{~h}\right)$, digested with $6 \mathrm{M}$ aqueous hydrochloric acid, and dried under vacuum.

\section{Preparation}

All the 20 standard amino acids were classified into the following four groups based on their Rf values to avoid merging of individual amino acids during elution. These are Group-1: asparagin, glutamine, serine, proline, and 
methionine; Group-2: aspartic acid, glutamic acid, alanine, valine, and phenyl alanine; Group-3: lysine, glycine, threonine, tyrosine, and isoleucine; Group-4: histidine, argentine, cysteine, tryptophan, and leucine. Each group consisted of $1 \mathrm{mg}$ of each of the five amino acids dissolved with $5 \mathrm{ml}$ distilled water.

\section{Analysis}

The powdered sample was dissolved in distilled water, and $5 \mu \mathrm{l}$ of sample was loaded on 8 -mm-thick pre-coated silica gel $60 \mathrm{~F}_{254}$ TLC plate $(20 \mathrm{~cm} \times 15 \mathrm{~cm})$ and processed in a CAMAG-LINOMAT 5 instrument. The plate was developed in butane-ammonia-pyridine-water (3.9:1:3.4:2.6) mobile phase. The plate was sprayed with a ninhydrin reagent prepared in propan-2-ol and dried. The developed plate was documented using a photo-documentation chamber (CAMAG-REPROSTAR 3) at UV 254-nm and UV $366-\mathrm{nm}$ lights. Finally, the plate was scanned at $500 \mathrm{~nm}$ using a CAMAG-TLC SCANNER 3. The peak area of the sample was compared with standard amino acids and quantified.

\section{Analysis of DNA}

The preparation and analysis of proteins by SDS-PAGE was done following the method of Sambrook et al. (1989).

\section{Extraction}

Isolation of DNA was done in the muscle tissue of PL after 90 days of dietary treatment. The DNA extracts isolated was subjected to the qualitative analysis by agarose gel electrophoresis.

\section{Preparation}

Concentration of the DNA in each samples was determined using a spectrophotometer. The absorbance ratio was calculated between 260 and $280 \mathrm{~nm}$.

\section{Analysis}

The amount and integrity of DNA was determined visually after electrophoresis. Equal amounts of DNA samples were loaded onto $1 \%$ agarose. Ethidium bromide was incorporated into the gel before polymerization. Gel was allowed to run at $50 \mathrm{~V}$ and after completion of the run; the same was observed under UV illuminator.

\section{Results}

The results of SDS-PAGE electrophoresis, HPTLC analysis of amino acids, and agarose gel electrophoresis are presented.

\section{Proteins}

$14-$ to $116-\mathrm{kDa}$ proteins were identified. $66-\mathrm{kDa}$, $41-\mathrm{kDa}, 15-\mathrm{kDa}$, and $13-\mathrm{kDa}$ proteins were highly intense in the groups fed with $5 \%$ A. sativum, $1 \%$ C. longa, and $5 \%$ Z. officinale. $33-\mathrm{kDa}$ and $25-\mathrm{kDa}$ proteins were exclusively present only in these groups (Fig. 1).

\section{Amino acids}

Z. officinale supplementation increased the proportions of lysine, methionine, leucine, and valine (essential amino acids); glycine, serine, tyrosine, and asparagine (non-essential amino acids); and cysteine and proline (conditionally essential amino acids) (Figs. 2, 3, 4, and 5).

\section{DNA}

Lane holding DNA sample of $5 \%$ Z. officinale supplementation showed a high intense DNA band of relatively high molecular weight (Fig. 6).

\section{Discussion}

Feed acts as a source of proteins, carbohydrates, lipids, vitamins, and minerals. Nutrition is used to manipulate the growth patterns of animals. The feed efficiency (FE) denotes utilization of these essential elements favoring growth and other physiological activities of the prawn. The FE patterns of the corresponding groups are reported by Rebecca and Bhavan (2014). The superior protein profile pattern is attributed to the increased FE with $Z$. officinale supplementation. Reduced feed efficiency in the control group resulted in only minimal protein fraction available for protein synthesis and in failure to produce new proteins for growth. The presence of $33-\mathrm{kDa}$ and $25-\mathrm{kDa}$ protein bands and intensification of $66-\mathrm{kDa}$, $41-\mathrm{kDa}, 15-\mathrm{kDa}$, and $13-\mathrm{kDa}$ protein bands in the groups fed with $5 \% A$. sativum, $1 \%$ C. longa, and $5 \% Z$. officinale is a result of protein anabolism. Protein anabolism is reflected by increased protein synthesis in these groups and is greatly influenced by nutrient intake. The intensity corresponds to the relative abundance of individual polypeptides or many different polypeptides having very similar molecular masses. It is principally due to various basic-charged proteins that would become exposed due to unfolding, resulting in increased interaction with the Coomassie blue dye molecules. Faadila et al. (2013) reported the presence of high-intensity protein bands in the well-fed prawns.

Growth has important implication in animal production because it significantly influences the value of the animal being produced. Muscle fibers are predominantly protein, and fiber size is determined by the rate of protein synthesis (Weinert, 2009). The composition of polypeptide bands is reported to have textural changes in $M$. rosenbergii (Sriket, Benjakul, \& 


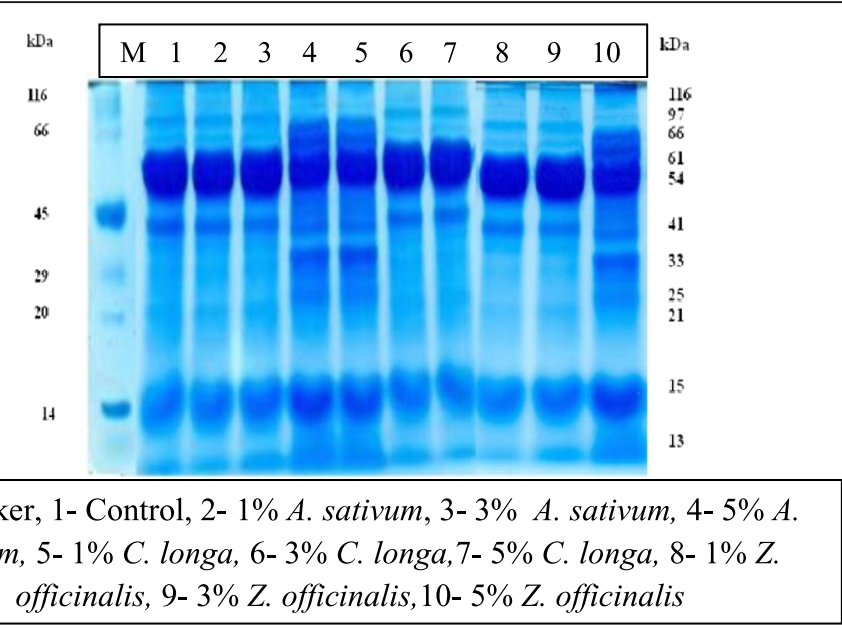

Fig. 1 SDS-PAGE gel

Visessanguan, 2010). A. sativum, C. longa, and Z. officinale are reported to increase the digestive enzyme activity in $M$. rosenbergii post larva (Rebecca, Bhavan, \& Radhakrishnan, 2014). Bhavan et al. (2013) reported a similar protein profile of $M$. rosenbergii PL-15 on $5 \% Z$. officinale supplementation with a similar basal feed mix. Major changes have been reported between $33-\mathrm{kDa}$ and $25-\mathrm{kDa}$ regions. Supplementation of $A$. sativum, C. longa, and $Z$. officinale in $M$. rosenbergii PL-5 with a similar basal feed mix is reported to increase protein synthesis (Poongodi, Bhavan, Muralisankar, \& Radhakrishnan, 2012).

Herbal active compounds have the potential to increase protein production in the tissues. Medicinal plants are a natural storehouse of alkaloids, flavonoids, pigments, phenolics, terpenoids, steroids, and essential oils. They are reported to promote various activities like

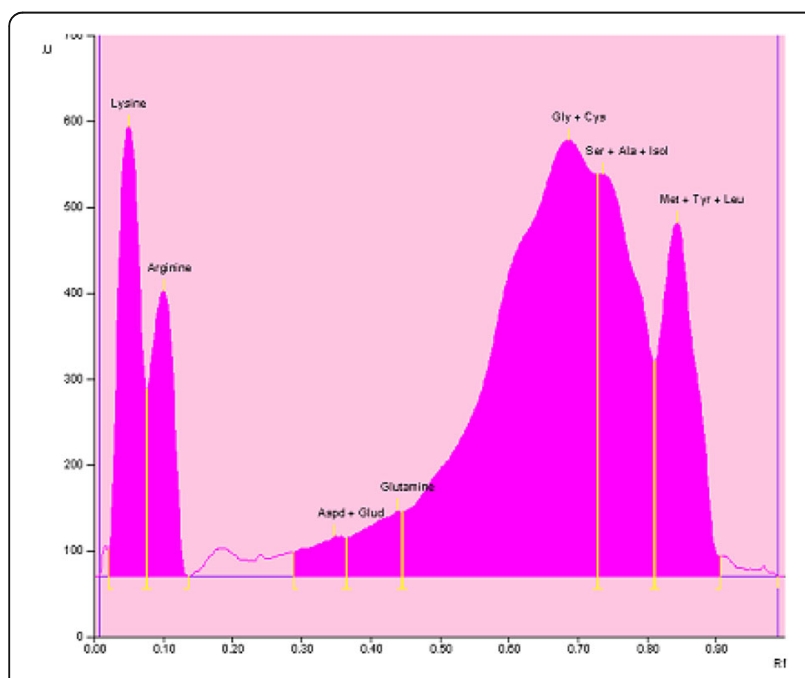

Fig. 2 HPTLC chromatogram for the control group growth promotion, immune stimulation, antioxidation, increase in the rate of transcription leading to increased RNA, total amino acid synthesis, and finally increase production of proteins in the cells (Citarasu, 2010). A. sativum and $Z$. officinale have known to increase protein intake (Al-Salahy, 2002; Venkatramalingam et al., 2007). Deficiencies of one or more essential amino acids limit protein synthesis and growth or both (Litaay, De Silva, \& Gunasekera, 2001), which forms the basis for a reduced level of protein synthesis in the control group. Lysine and methionine are two limiting amino acids present in plant proteins. Alanine and aspartate are often used to balance nitrogen in aquatic species. Cysteine, proline, and glutamine are conditionally essential amino acids in which proline is traditionally thought to be a dispensable amino acid for fish and promote feed intake (Li, Mai, Trushenski, \& Wu, 2009). The control

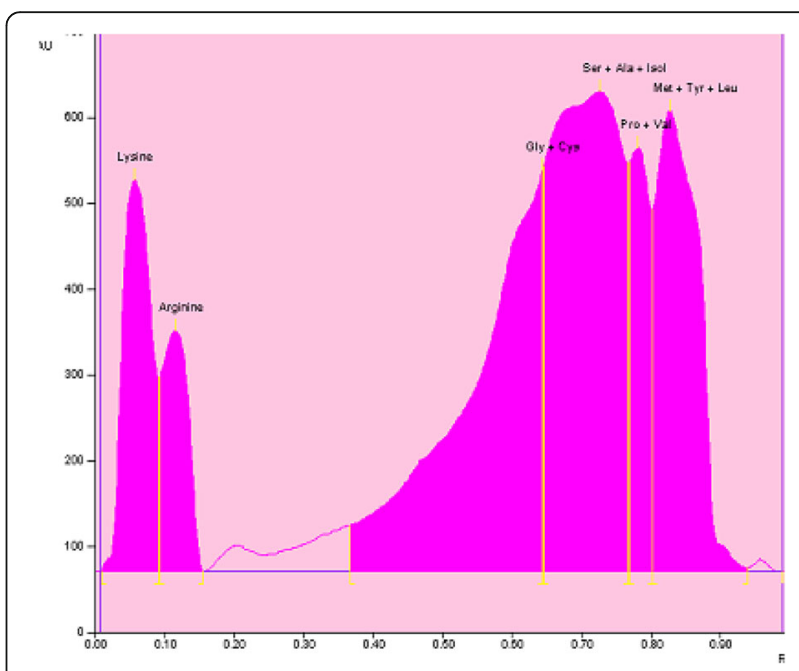

Fig. 3 HPTLC chromatogram for $5 \%$ A. sativum 


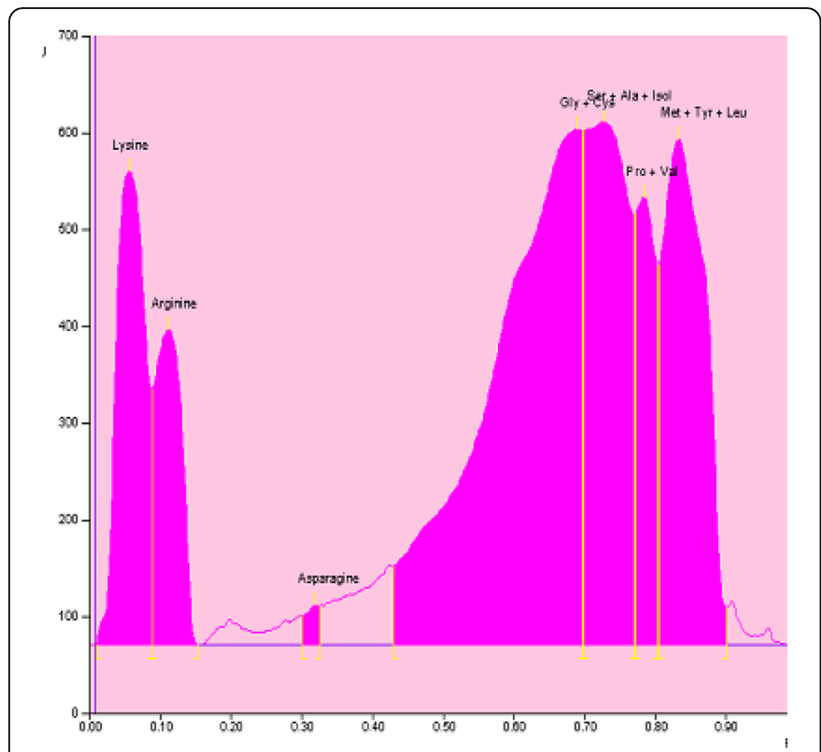

Fig. 4 HPTLC chromatogram for 1\% C. longa

group possesses considerable proportions of aspartic acid, glutamic acid, and glutamine. However, these are non-essential amino acids in $M$. rosenbergii (Farmanfarmaian \& Lauterio, 1980).

Intense DNA bands in the groups with herbal supplementation indicates a high proportion of DNA corresponding to increased DNA synthesis as reported with A. sativum by Tsuchiya and Nagayama (2008) by enhancing the membrane fluidity of mitochondria in glioma cells together with promoting the thymidine incorporation into DNA, resulting in the stimulation of cell growth and DNA synthesis or through a potential antioxidant system (enzymatic and non-enzymtic) as reported with $C$. longa in the presence of vitamin $\mathrm{C}$

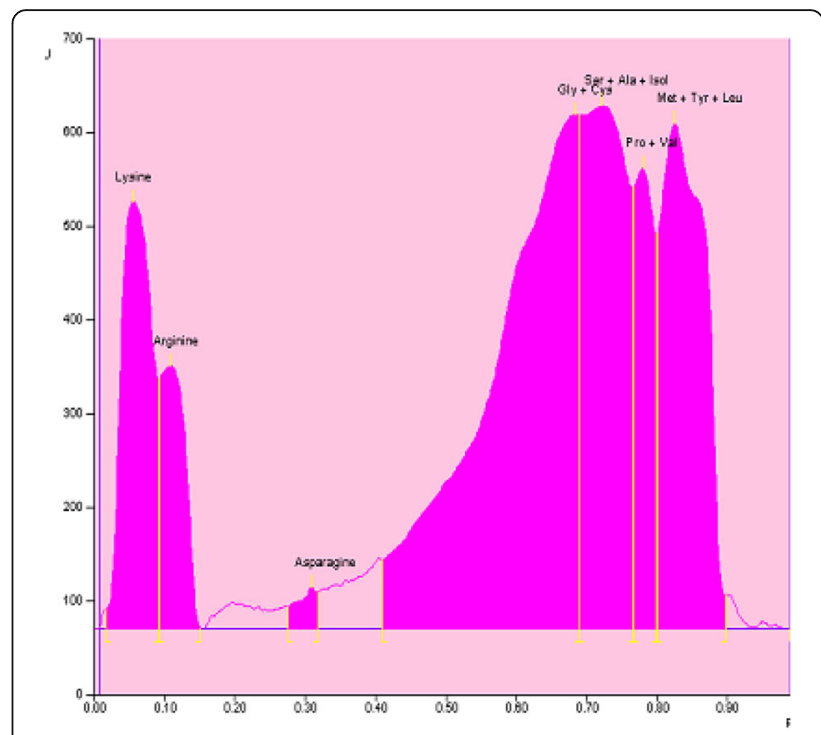

Fig. 5 HPTLC chromatogram for $5 \%$ Z. officinale

and curcumin (Menon \& Sudheer, 2007), and gingerol, shogaols, zingerone/vanillylacetone, paradol, and curcuminoids in Z. officinale (Kim, Kim, Na, Surh, \& Kim, 2007).

\section{Conclusion}

Nutrient profiles of $M$. rosenbergii orally supplemented with prebiotic composites, namely, A. sativum, C. longa, and $Z$. officinale, promoted protein synthesis, amino acid synthesis, and stability of DNA, hypothetically due to an increased rate of transcription and antioxidative role of nutraceuticals/nutritional phytochemicals such as alkaloids, flavonoids, pigments, phenolics, terpenoids, steroids, and essential

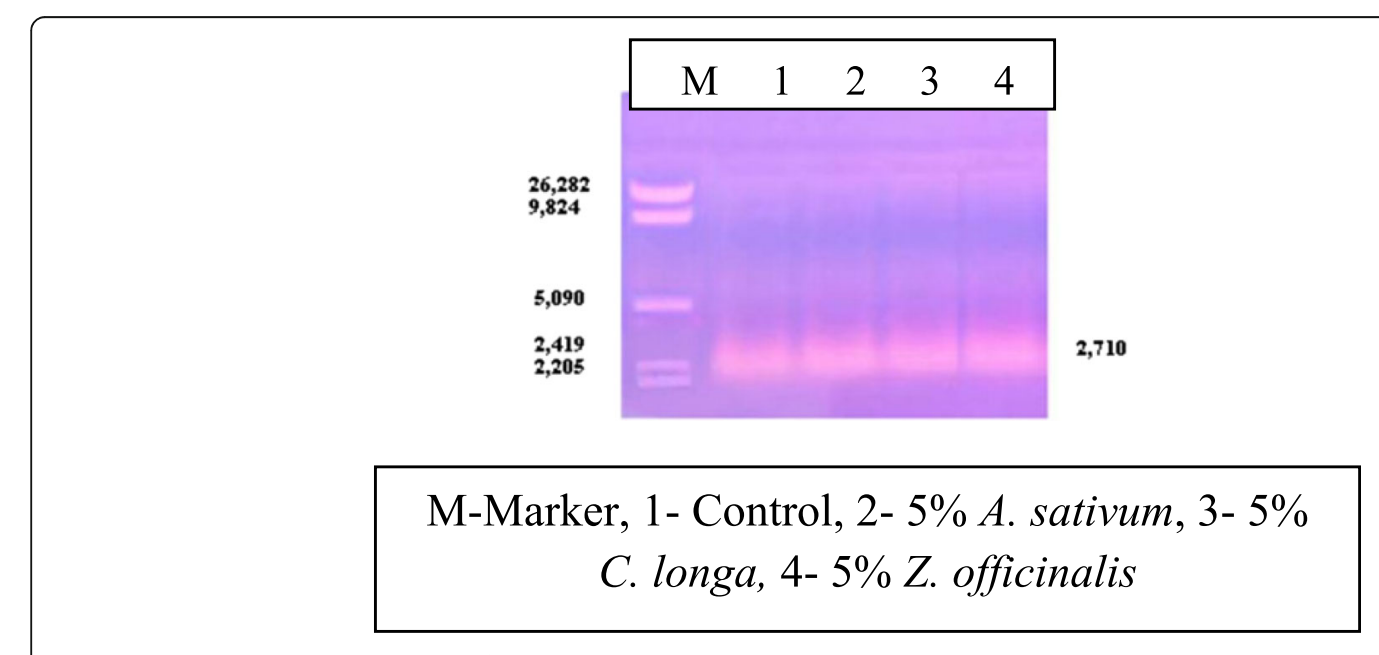

Fig. 6 Agarose gel electrophoretic profile 
oils present in them, possibly improving the rate of metabolism. $Z$. officinale as a potent bioenhancer/absorption enhancer promoted growth and suitability by promoting feed efficiency and protein intake, possibly making all proteins available for intake as discussed.

\section{Acknowledgements}

The Department of Zoology, Bharathiar University, is greatly acknowledged for hosting the research environment.

\section{Funding}

This article is a part of Ph.D research, funded by the Department of Science and Technology, Ministry of Science and Technology, India.

\section{Availability of data and materials}

The dataset supporting the conclusions of the present article is included within the article and its additional files.

\section{Authors' contributions}

AAR contributed to the lab-based research work and article editing. PSB contributed to all essential research supervision. Both authors read and approved the final manuscript.

Ethics approval and consent to participate Not applicable.

\section{Consent for publication}

Not applicable.

\section{Competing interests}

The authors declare that they have no competing interests.

\section{Publisher's Note}

Springer Nature remains neutral with regard to jurisdictional claims in published maps and institutional affiliations.

\section{Author details}

'Department of Zoology, PSG College of Arts and Science, Coimbatore, Tamilnadu 641014, India. ${ }^{2}$ Unit of Crustacean Biology, Department of Zoology, Bharathiar University, Coimbatore, Tamilnadu 641046, India.

Received: 29 October 2017 Accepted: 7 January 2019

Published online: 11 February 2019

\section{References}

Al-Salahy, M. B. (2002). Some physiological studies on the effect of onion and garlic juices on the fish, Clarias lazera. Fish Physiology and Biochemistry, 27, $129-142$

Bhavan, P. S., Radhakrishnan, S., Seenivasan, C., Shanthi, R., Poongodi, R., \& Kannan, S. (2010). Proximate composition and profiles of amino acids and fatty acids in the muscle of adult males and females of commercially viable prawn species Macrobrachium rosenbergii collected from natural culture environments. International Journal of Biology, 2, 107-119.

Bhavan, P. S., Saranya, C., Manickam, N., Muralisankar, T., Radhakrishnan, S., \& Srinivasan, V. (2013). Effects of Piper longum, Piper nigram and Zingiber officinale on survival, growth, activities of digestive enzymes and contents of total protein, vitamins and minerals in the freshwater prawn Macrobrachium rosenbergii. Elixir Biotechnology, 58, 14824-14828.

Citarasu, T. (2010). Herbal biomedicines: a new opportunity for aquaculture industry. Aquaculture International, 18, 403-414

Devi, D. V. P., Hareesh, K., \& Reddy, M. S. (2015). Studies on the proximate composition of tropical freshwater prawn Macrobrachium rosenbergii. International Journal of Fisheries and Aquatic Studies, 3(1), 329-336.

El-Sayed, A. M. (1999). Alternative protein sources for farmed tilapia, Oreochromis spp. Aquaculture, 179, 149-168.

Faadila, N. M. I., Harivaindaran, K. V., \& Yang, T. A. (2013). Biochemical and texture property changes during molting process of tiger prawn, Penaeus monodon. International Food Research Journal, 20(2), 751-758.
Farmanfarmaian, A., \& Lauterio, T. (1980). Amino acid composition of the tail muscle of Macrobrachium rosenbergii, comparison to amino acid patterns of supplemented commercial feed pellets. Proceedings of the World Mariculture Society, 11, 454-462.

Hess, B., \& Sherma, J. (2004). Quantification of arginine in dietary supplement tablets and capsules by silica gel high performance thin layer chromatography with visible mode densitometery. Acta Chromatographica, 14, 60-69.

Hoffman, K. (1977). The influent of heat on meat proteins studied by SDS electrophoresis. In T. Hřyem, \& O. Kville (Eds.), Physical chemical and biological changes in food caused by thermal processing, (pp. 311-327). London: Applied Science Publisher.

Hutkins, R. W., Krumbeck, J. A., Bindels, L. B., Cani, P. D., Fahey, G. Jr., Goh, Y. J., Hamaker, B. Martens, E. C., Mills, D. A., Rastal, R. A., Vaughan, E., Sanders, M. E. (2016). Prebiotics: why definitions matter. Current Opinion in Biotechnology, $37: 1-7$

Kesarwani, K., \& Gupta, R. (2013). Bioavailability enhancers of herbal origin: an overview. Asian Pacific Journal of Tropical Biomedicine, 3(4), 253-266.

Keshavanath, P., Gangadhara, B., \& Khadri, S. (2003). Growth enhancement of carp and prawn through dietary sodium chloride supplementation. Aquaculture Asia, 8, 4

Kim, J. K., Kim, Y., Na, K. M., Surh, Y. J., \& Kim, T. Y. (2007). [6]- Gingerol prevents UVB-induced ROS production and COX-2 expression in vitro and in vivo. Free Radical Research, 41, 603-614.

Kurhekar, J. (2013). Curcuma longa and Allium sativum as prebiotics. Bionano frontier. 6, 327-329.

Laemmli, U. K. (1970). Cleavage of structural proteins during the assembly of the head of bacteriophage T4. Nature, 227(5259), 680-685.

Li, P., Mai, K. S., Trushenski, J., \& Wu, G. (2009). New developments in fish amino acid nutrition: towards functional and environmentally oriented aquafeeds. Amino Acids, 37, 43-53.

Litaay, M., De Silva, S. S., \& Gunasekera, R. M. (2001). Changes in the amino acid profiles during embryonic development of the blacklip abalone (Haliotis rubra). Aquatic Living Resources, 14, 335-342.

Lowry, O. H., Rosenbrough, W. J., Fair, A. L., \& Randall, R. J. (1951). Protein measurement with the Folin phenol reagent. The Journal of Biological Chemistry, 193, 265-275.

Lu, Q. Y., Summanen, P. H., Lee, R. P., Huang, J., Henning, S. M., Heber, D., ... Li, Z. (2017). Prebiotic potential and chemical composition of seven culinary spice extracts. Journal of Food Science, 82(8), 1807-1813.

Menon, V. P., \& Sudheer, A. R. (2007). Antioxidant and anti-inflammatory properties of curcumin. Advances in Experimental Medicine and Biology, 595, $105-125$.

Mona, M. H., Rizk, E. S. T., Salama, W. M., \& Younis, M. L. (2015). Efficacy of probiotics, prebiotics, and immunostimulant on growth performance and immunological parameters of Procambarus clarkii juveniles. The Journal of Basic \& Applied Zoology, 69, 17-25

Nandlal, S., \& Pickering, T. (2005). Freshwater prawn Macrobrachium rosenbergil farming in Pacific Island countries. Hatchery operation, (vol. 1, pp. 1-15). Noumea: Secretariat of the Pacific Community.

Poongodi, R., Bhavan, P. S., Muralisankar, T., \& Radhakrishnan, S. (2012). Growth promoting potential of garlic, ginger, turmeric and fenugreek on the freshwater prawn Macrobrachium rosenbergii. International Journal of Pharma and Bio Sciences, 3(4), 914-926.

Rebecca, A., \& Bhavan, P. S. (2011). Growth performance of Macrobrachium rosenbergii post larvae fed with vegetable wastes and palm olein supplemented formulated feeds. Recent Research in Science and Technology, 3, 69-76.

Rebecca, A. A., Bhavan, P. S., \& Radhakrishnan, S. (2014). Allium sativum, Zingiber offi cinale- and Curcuma longa-induced digestive and antioxidant enzyme activities in Macrobrachium rosenbergii post larvae. International Journal of Life Sciences, 3(1), 22-27.

Rebecca, A. A., \& Bhavan, P. S. (2014). Growth promotion and survival enhancement of the freshwater prawn Macrobrachium rosenbergii post larvae fed with Allium sativum, Zingiber officinale and Curcuma longa. International Journal of Pure and Applied Zoology, 2(2), 138-149.

Sambrook, J., Fritsch, E. F., \& Maniatis, T. (1989). Molecular cloning: a laboratory manual, (pp. 1-3). New York: Cold Spring Harbor Laboratory Press.

Shylaja, M. R., \& Peter, K. V. (2007). Spices in the nutraceutical and health food industry. Acta Horticulturae, 756, 369-378

Sriket, C., Benjakul, S., \& Visessanguan, W. (2010). Post-mortem changes of muscle from fresh water prawn (Macrobrachium rosenbergii) as influenced by spawning stages. Food Science and Technology, 43, 608-616. 
Tatiraju, D. V., Bagade, V. B., Karambelkar, P. J., Jadhav, V. M., \& Kadam, V. (2013). Natural "bioenhancers: an overview". Journal of Pharmacognosy and Phytochemistry, 2(3), 55-60.

Tsuchiya, H., \& Nagayama, M. (2008). Garlic allyl derivatives interact with membrane lipids to modify the membrane fluidity. Journal of Biomedical Science, 15, 653.

Venkatramalingam, K \& Christopher, G \& Citarasu, T. (2007). Zingiber officinalis an herbal appetizer in the tiger shrimp Penaeus monodon (Fabricius) larviculture. Aquaculture Nutrition, 13, 439-443.

Wagner, J. J., \& Stanton, T. L. (2012). Formulating rations with the Pearson square, (vol. 01, p. 618). Colorado State University Extension.

Weinert, D. J. (2009). Nutrition and muscle protein synthesis: a descriptive review. The Journal of the Canadian Chiropractic Association, 53(3), 186-193.

Submit your manuscript to a SpringerOpen ${ }^{\mathcal{O}}$ journal and benefit from:

- Convenient online submission

- Rigorous peer review

- Open access: articles freely available online

- High visibility within the field

- Retaining the copyright to your article

Submit your next manuscript at $\boldsymbol{\nabla}$ springeropen.com 